\title{
Recent Advances in Modelling and Implementation of Rainwater Harvesting Systems towards Sustainable Development
}

\author{
Ataur Rahman \\ School of Computing, Engineering and Mathematics, Western Sydney University, Locked Bag 1797, Penrith, \\ NSW 2751, Australia; a.rahman@westernsydney.edu.au; Tel.: +61-2-4736-0145
}

Received: 9 October 2017; Accepted: 6 December 2017; Published: 8 December 2017

\begin{abstract}
Rainwater harvesting (RWH) is perhaps the most ancient practice to meet water supply needs. It has received renewed attention since the 1970s as a productive water source, water savings and conservation means, and sustainable development tool. In $\mathrm{RWH}$, it is important to know how much water can be harvested at a given location from a given catchment size, whether the harvested water meets the intended water quality, whether the RWH system is economically viable and whether the state regulations favor the RWH. Furthermore, the selected RWH system should be suitable to local rainfall and field conditions, downstream impacts, and socio-economic and cultural characteristics. In this regard, this paper provides an overview of the special issue on "Rainwater Harvesting: Quantity, Quality, Economics and State Regulations". The selected papers cover a wide range of issues that are relevant to RWH such as regionalization of design curves, use of spatial technology, urban agriculture, arid-region water supply, multi criteria analysis and application of artificial neural networks.
\end{abstract}

Keywords: rainwater harvesting; water quality; water conservation; rainwater tanks; life cycle cost analysis; multi criteria analysis; urban flooding

\section{Introduction}

Rainwater harvesting (RWH) is a centuries old water supply technology and plays a major role to meet ever increasing water demand and cope with the climate change and variability. RWH is defined as a method of inducing, collecting, storing, and conserving local surface runoff for subsequent use. The RWH system collects rainwater from impervious surfaces (e.g., rooftops, terraces, courtyards and road surfaces) or natural land surface and stores water in a storage system such as tanks, cisterns and subsurface dams for both indoor and outdoor use [1,2]. In remote regions, RWH contributes towards meeting one of the targets of Sustainable Development Goals (ensuring availability and sustainable management of water and sanitation for all). In urban areas, the rainwater harvesting (RWH) system is generally used as an alternative water supply means for the non-potable purposes (e.g., toilet flushing, laundry, irrigation and car washing), and for control of stormwater [3,4]. The RWH system is also used as a water source for small scale agricultural needs in both urban and rural areas. RWH is a primary water source in many rural areas and on islands [4]. Wider implementation of the RWH system can delay the construction of new water supply infrastructures such as dams and pipelines. RWH enhances water availability for domestic and agricultural needs in semi-arid regions [2]. In areas of increasing water scarcity, the RWH system can provide a more resilient and cost-efficient means of enhancing water security than the complex public water supply system [5].

The evolution of the RWH system has been reviewed by a number of authors, e.g., [1,6-9]. The effectiveness of the RWH system in water savings and conservation has been demonstrated across the globe covering a wide range of climatic conditions and applications, e.g., in Australia [10], 
in Germany [11], in the USA [6], in Brazil [12], in the UK [13], in Italy [14], in China [15], in South Korea [16] and in West Asia and North Africa [9,17-20]. The quality of harvested rainwater largely depends on the surrounding environment, the tank material and maintenance of the RWH system. Rainwater harvested from the roof catchments may contain heavy metals and nutrients [21,22]. Use of adequately designed first flush devices and regular maintenance of the RWH system (such as washing of roof surfaces, gutters, tanks and first flush devices, inspecting for points of entry for mosquitoes and vermin and removing overhanging trees from the rooftop) can significantly improve the harvested water quality $[23,24]$.

The modelling of the RWH system seeks to match the rainwater availability with the projected water demand $[4,25]$. This is generally undertaken by continuous simulation of the inflow and outflow [26-28] or using empirical relationships [4,29,30] or stochastic analysis [6,31] or a web-based tool that integrates geo-referenced rainfall patterns [32]. RWH system is also analyzed as a stormwater management component [33-35]. Incorporation of environmental objectives (e.g., greenhouse gas emission and materials used in construction of RWH system) into the design of the RWH system can significantly affect the determination of appropriate tank size [36]. Similarly, the impact of climate change consideration can also affect the tank size [37].

The economic analysis of RWH system needs to consider the cost implications of a whole range of issues such as quantity of water saved, water price, interest rate, environmental benefits, productive use and saved time for fetching water (which can be used for other productive uses, the cost of alternative water supplies and maintenance of the RWH system [7,9]. Previous studies on economic analysis of the RWH system have often demonstrated conflicting results depending on the issues considered in the analysis as explained in Campisano et al. [1] and Amos et al. [7]. Some researchers have shown that the RWH system is not financially viable in their considered scenarios [38-40], while other researchers have found that it is financially viable in specific cases [41-43]. These differences in conclusions can be attributed to the way maintenance and operational costs were incorporated into the analysis (e.g., energy cost to run the pump, maintenance of the RWH system and tank life), availability and cost of other sources of water and consideration of multiple benefits offered by the RWH system (e.g., productive water use [9] and environmental benefits).

The research on RWH is getting broader covering aspects such as water savings and conservation, stormwater management, urban agriculture, economic analysis and environmental issues. In this regard, this special issue contains nine articles covering modelling, regionalization, uncertainty analysis, water-energy nexus, sustainability and urban flood mitigation, the contents of which are analyzed in the following section.

\section{Summary of This Special Issue}

Use of spatial information in the modelling and analysis of RWH system is becoming popular. To supplement water supply in Mombasa, Ojwang et al. [44] demonstrated that a combination of satellite image analysis and modelling could be used as effective tools for developing RWH policy. In this study, image classification techniques were used to detect roof areas with reasonable accuracy. They also considered future population growth, improved living standards and future climate scenarios in the analysis. They noted that the RWH system could provide 2.3 to 23 million cubic meters of water, which, however, was not enough to meet the full water demand in the study area. This study will be a useful reference to RWH system design in future based on satellite image analysis.

The RWH system can offer significant water savings and conservation benefits even in the arid regions. For the Oum Zessar watershed in southeastern Tunisia, which is a semi-arid region, Adham et al. [45] developed an RWH system design methodology that integrated engineering, biophysical and socio-economic criteria using the Analytical Hierarchy Process (AHP) aided by the Geographic Information System (GIS). In this method, establishment of the scores/weighting for selected criteria was dependent on expert opinion. This integrated method was successfully applied to the study area, which provided suitability scores to the candidate RWH sites. The developed 
methodology was found to be highly flexible and easy to adapt to other regions. This methodology will be useful to designers and decision makers across different countries for enhancing the performance of existing and new RWH sites.

Regionalization of RWH system parameters assists the designers and planners in implementing the RWH system without the need of formal data analysis, which is often time-consuming. In this regard, Sámano-Romero et al. [46] used regional water access and precipitation data in Mexico to identify municipalities that would most benefit from the installation of domestic RWH systems. The developed method considered monthly rainfall data, number of occupants per household, water demand and run-off coefficient to calculate catchment area and tank size needed for a single dwelling. A curve was then developed to estimate catchment area based on annual rainfall for the selected municipalities that resulted in an average catchment area of $113.3 \mathrm{~m}^{2}$ for a water demand of $100 \mathrm{~L} /$ capita/day. This study demonstrated that regional approximation could assist in the national implementation of the RWH system.

The RWH system offers many other benefits than savings of mains water. In this regard, Melville-Shreeve et al. [47] adopted a quantitative multi criteria analysis to assess the RWH system under a range of emerging criteria in the UK. They noted that traditional design approaches of the RWH system adopt whole life cost assessments that aim for financial savings associated with the provision of an alternative water supply, which disregard broader benefits of RWH system such as stormwater management issue. They proposed a number of RWH system configurations that would outperform traditional RWH system in relation to benefits and cost. The outcomes of this study will result in cost-effective implementation of RWH system in the UK. The approach can be adapted to other countries to demonstrate the wider benefit of RWH system.

In another RWH system regionalization study, Liuzzo et al. [48] assessed the reliability of using RWH system to provide water for toilet flushing and garden irrigation for a typical single-family home scenario in Sicily, Italy. Data on water consumption was collected and a daily water balance model was developed, and the model performance was evaluated using rainfall data over 100 stations in Sicily. Based on regional analysis, annual reliability curves for the RWH system as a function of mean annual rainfall was developed, which would be used by the designers and planners in the region. An uncertainty analysis was undertaken to evaluate the accuracy of the developed regional design curves. The benefit-cost analysis revealed that the implementation of an RWH system in Sicily could provide environmental and economic advantages over traditional water supply methods.

Irrigation by the RWH system in urban areas is getting renewal attention. On this issue, Liang et al. [49] evaluated the role of non-technological factors in RWH for agriculture irrigation in Beijing. In this study, 10 non-technological and technological impact factors were chosen and thereafter, based on an artificial data mining method and rough set analysis, the decisive factors were found. The most important finding of this study was that two non-technological factors, "doubts about rainwater quality" and "the availability of groundwater" largely defined the success of the RWH system in Beijing. They suggested that it is important to enhance public confidence and to motivate users on utilizing rainwater for agriculture irrigation to make the RWH system sustainable. This study highlights that non-technological factors such as public perception and motivation are important along with technological factors such as reliability and financial benefits of the RWH system.

The RWH system can contribute positively towards the water-energy nexus. In this regard, Chiu et al. [50] investigated the water-energy issue in relation to the RWH system in Taiwan. They presented a geographic information systems (GIS)-simulation-based design system to investigate whether the RWH system can be cost-effectively designed as an innovative water-energy conservation scheme on a regional level. They integrated a rainfall database, water balance model, spatial technologies, energy-saving investigation, and economic feasibility analysis for eight communities in Taipei, Taiwan. They exploited the temporal and spatial variations in rainfall to enhance the evaluation of the RWH system. The interesting finding of this study was that the RWH system became feasible based on the optimal design when both water and energy-savings were considered. They found that 
RWH could achieve $21.6 \%$ domestic water-use savings and 138.6 ( $\mathrm{kWh}$ /year-family) energy-savings. The findings of this study will assist RWH research in the water-energy nexus, which could also include urban agriculture supported by the RWH system to contribute towards the water-energy-food nexus.

The RWH system can be used to mitigate urban flooding, which is a relatively new area of RWH research. In this regard, Huang et al. [51] integrated the RWH system with the popular stormwater runoff management model (SWMM) in Zhong-He District, Taiwan. They adopted fuzzy C-means clustering to form similar subregions based on urban roof, land use and drainage systems. Based on statistical quartiles analysis for rooftop area and rainfall frequency analysis, they simulated the corresponding reduced flooding circumstances. They also applied a backpropagation neural network for developing a water level simulation model of urban drainage systems to substitute for SWMM, and a tabu search-based algorithm was adopted with the embedded backpropagation neural network based SWMM to optimize the planning solution. They found that the optimized spatial RWH system could reduce $72 \%$ of flood inundation losses based on the simulated flood events. The developed RWH modelling framework can be adapted to other cities having significant flooding problems.

In cities with limited rainfall and inadequate water supply, the RWH system can assist with solving water problems. In a study in Pachuca and Mineral de la Reforma, State of Hidalgo, Central Mexico by Lizárraga-Mendiola et al. [52] demonstrated that the harvestable rainwater from a roof area of $45 \mathrm{~m}^{2}$ and $50 \mathrm{~m}^{2}$ would be sufficient most of the year to meet toilet flushing and washing machine water demand; however, $100 \mathrm{~m}^{2}$ and $200 \mathrm{~m}^{2}$ roof area could provide enough water to meet other water demand too.

\section{Conclusions}

RWH contributes towards meeting one of the targets of the Sustainable Development Goals by serving as the principal water supply means for the remote and drought-prone regions and by saving a significant volume of mains water and offering substantial environmental benefits.

This special issue has covered a wide range of contemporary issues on RWH as summarized below. Development of design curves for the RWH system assists wider application of the RWH system in a region without the need of at-site data analysis as demonstrated by Sámano-Romero et al. [46] and Liuzzo et al. [48]. The feasibility and benefits of implementing the RWH system is likely to be underestimated if only monetary benefit is considered [50]. Other benefits, such as greenhouse gas emission reduction, urban stormwater runoff mitigation, reducing water stress during peak hours, and decreased demand on current water and energy facilities, should not be neglected in evaluating the RWH system. Use of spatial technology will make RWH system modelling more effective in identifying roof areas and other impervious areas and flood-prone areas for urban flood mitigation purpose as highlighted in Ojwang et al. [44], Adham et al. [45], Chiu et al. [50] and Huang et al. [51]. The RWH system can be used effectively for urban flood mitigation, which is a major problem in many cities around the world. The RWH modelling framework developed by Huang et al. [51] is capable of selecting a flexible and practical spatial arrangement and capacity design approach for RWH to serve as an alternative means for urban flood mitigation. The RWH system can assist in solving water supply problems even in arid regions as noted by Lizárraga-Mendiola et al. [52] and Adham et al. [45]. A similar conclusion was reached by Hajani and Rahman [28]. The RWH system can contribute positively to the water-energy-food nexus in urban areas, which is a relatively new area in RWH research $[49,50]$. The use of new data analysis techniques such as quantitative multi criteria analysis [47] and artificial neural networks [51] can demonstrate enhanced viability of the RWH system.

Further research on RWH should focus on financial analysis covering multiple benefits, life cycle analysis incorporating energy use and greenhouse gas emission, productive water use such as boosting rural and urban agriculture, and institutional and socio-political support to improve acceptability of RWH. 
Acknowledgments: The author of this paper and editor of this special issue would like to thank three anonymous reviewers for their constructive suggestions to improve this editorial, all authors for their notable contributions to this special issue, the reviewers for devoting their time and efforts to reviewing the manuscripts and the Water Editorial team for their great support during the review of the submitted manuscripts.

Conflicts of Interest: The author declares no conflict of interest.

\section{References}

1. Campisano, A.C.; Butler, D.; Ward, S.; Burns, M.J.; Friedler, E.; DeBusk, K.; Fisher-Jeffes, L.N.; Ghisi, E.; Rahman, A.; Furumai, H.; et al. Urban rainwater harvesting systems: Research, implementation and future perspectives. Water Res. 2017, 115, 195-209. [CrossRef] [PubMed]

2. Lasage, R.; Verburg, P.H. Evaluation of small scale water harvesting techniques for semi-arid environments. J. Arid Environ. 2015, 118, 48-57. [CrossRef]

3. Van der sterren, M.; Rahman, A.; Dennis, G.R. Implications to stormwater management as a result of lot scale rainwater tank systems: A case study in Western Sydney, Australia. Water Sci. Technol. 2012, 65, 1475-1482. [CrossRef] [PubMed]

4. Hanson, L.S.; Vogel, R.M. Generalized storage-reliability-yield relationships for rainwater harvesting systems. Environ. Res. Lett. 2014, 9, 075007. [CrossRef]

5. Batchelor, C.; Fonseca, C.; Smits, S. Life-Cycle Costs of Rainwater Harvesting Systems; IRC International Water and Sanitation Centre: The Hague, The Netherlands, 2011; Volume 46, p. 37.

6. Basinger, M.; Montalto, F.; Lall, U. A rainwater harvesting systems reliability model based on nonparametric stochastic rainfall generator. J. Hydrol. 2010, 392, 105-118. [CrossRef]

7. Amos, C.C.; Rahman, A.; Gathenya, J.M. Economic analysis and feasibility of rainwater harvesting systems in urban and peri-urban environments: A review of the global situation with a special focus on Australia and Kenya. Water 2016, 8, 149. [CrossRef]

8. Pandey, D.N.; Gupta, A.K.; Anderson, D.M. Rainwater harvesting as an adaptation to climate change. Curr. Sci. 2003, 85, 46-59.

9. Bouma, J.A.; Hegde, S.S.; Lasage, R. Assessing the returns to water harvesting: A meta-analysis. Agric. Water Manag. 2016, 163, 100-109. [CrossRef]

10. Rahman, A.; Keane, J.; Imteaz, M.A. Rainwater harvesting in Greater Sydney: Water savings, reliability and economic benefits. Resour. Conserv. Recycl. 2012, 61, 16-21. [CrossRef]

11. Schuetze, T. Rainwater harvesting and management-Policy and regulations in Germany. Water Sci. Technol. Water Supply 2013, 13, 376-385. [CrossRef]

12. Ghisi, E.; Bressan, D.L.; Martini, M. Rainwater tank capacity and potential for potable water savings by using rainwater in the residential sector of southeastern Brazil. Build. Environ. 2007, 42, 1654-1666. [CrossRef]

13. Ward, S.; Butler, S. Rainwater harvesting and social networks: Visualizing interactions for niche governance, resilience and sustainability. Water 2016, 8, 526. [CrossRef]

14. Campisano, A.; Gnecco, I.; Modica, C.; Palla, A. Designing domestic rainwater harvesting systems under different climatic regimes in Italy. Water Sci. Technol. 2013, 67, 2511-2518. [CrossRef] [PubMed]

15. Gould, J.; Zhu, Q.; Yuanhong, L. Using every last drop: Rainwater harvesting and utilization in Gansu Province, China. Waterlines 2014, 33, 107-119. [CrossRef]

16. Han, M.Y.; Mun, J.S. Operational data of the Star City rainwater harvesting systems and its role as a climate change adaptation and a social influence. Water Sci. Technol. 2011, 63, 2796-2801. [CrossRef] [PubMed]

17. Ziadat, F.; Bruggeman, A.; Oweis, T.; Haddad, N.; Mazahreh, S.; Strtawi, W.; Syuof, M. A participatory GIS approach for assessing land suitability for rainwater harvesting in an arid rangeland environment. Arid Land Res. Manag. 2012, 26, 297-311. [CrossRef]

18. Oweis, T.; Hachum, A. Water harvesting and supplemental irrigation for improved water productivity of dry farming systems in West Asia and North Africa. Agric. Water Manag. 2006, 80, 57-73. [CrossRef]

19. Bruins, H.J.; Evenari, M.; Nessler, U. Rainwater harvesting agriculture for food production in arid zones: The challenge of the African famine. Appl. Geogr. 1986, 6, 13-32. [CrossRef]

20. Shariti, E.; Unami, K.; Mohawesh, O.; Fujihara, M. Design and construction of a hydraulic structure for rainwater harvesting in arid environment. In Proceedings of the 36th IAHR World Congress, Delft, The Netherlands, 28 June-3 July 2015. 
21. Van der Sterren, M.; Rahman, A.; Dennis, G. Quality and quantity monitoring of five rainwater tanks in Western Sydney, Australia. J. Environ. Eng. 2013, 139, 332-340. [CrossRef]

22. Hamdan, S.M. A literature based study of stormwater harvesting as a new water resource. Water Sci. Technol. 2009, 60, 1327-1339. [CrossRef] [PubMed]

23. Melidis, P.; Akratos, C.S.; Tsihrintzis, V.A.; Trikilidou, E. Characterization of rain and roof drainage water quality in Xanthi, Greece. Environ. Monit. Assess. 2007, 127, 15-27. [CrossRef] [PubMed]

24. Abdulla, F.A.; Al-Shareef, A.W. Roof rainwater harvesting systems for household water supply in Jordan. Desalination 2009, 243, 195-207. [CrossRef]

25. Hajani, E.; Rahman, A. Reliability and cost analysis of a rainwater harvesting systems in peri-urban regions of Greater Sydney, Australia. Water 2014, 6, 945-960. [CrossRef]

26. Ward, S.; Memon, F.A.; Butler, D. Performance of a large building rainwater harvesting systems. Water Res. 2012, 46, 5127-5134. [CrossRef] [PubMed]

27. Sample, D.J.; Liu, J. Optimizing rainwater harvesting systems for the dual purposes of water supply and runoff capture. J. Clean. Prod. 2014, 75, 174-194. [CrossRef]

28. Hajani, E.; Rahman, A. Rainwater utilization from roof catchments in arid regions: A case study for Australia. J. Arid Environ. 2014, 111, 35-41. [CrossRef]

29. Ghisi, E. Parameters influencing the sizing of rainwater tanks for use in houses. Water Resour. Manag. 2010, 24, 2381-2403. [CrossRef]

30. Eroksuz, E.; Rahman, A. Rainwater tanks in multi-unit buildings: A case study for three Australian cities. Resour. Conserv. Recycl. 2010, 54, 1449-1452. [CrossRef]

31. Unami, K.; Mohawesh, O.; Sharifi, E.; Takeuchi, J.; Fujihara, M. Stochastic modelling and control of rainwater harvesting systems for irrigation during dry spells. J. Clean. Prod. 2015, 88, 185-195. [CrossRef]

32. Fonseca, C.R.; Hidalgo, V.; Díaz-Delgado, C.; Vilchis-Francés, A.Y.; Gallego, I. Design of optimal tank size for rainwater harvesting systems through use of a web application and geo-referenced rainfall patterns. J. Clean. Prod. 2017, 145, 323-335. [CrossRef]

33. Van der sterren, M.; Rahman, A.; Shrestha, S.; Barker, G.; Ryan, G. An overview of on-site retention and detention policies for urban stormwater management in the greater Western Sydney region in Australia. Water Int. 2009, 34, 362-372. [CrossRef]

34. Campisano, A.; Modica, C. Appropriate resolution timescale to evaluate water saving and retention potential of rainwater harvesting for toilet flushing in single houses. J. Hydroinform. 2015, 17, 331-346. [CrossRef]

35. DeBusk, K.M.; Hunt, W.F.; Wright, J.D. Characterizing rainwater harvesting performance and demonstrating stormwater management benefits in the humid southeast USA. J. Am. Water Resour. Assoc. 2013, 49, 1398-1411. [CrossRef]

36. Morales-Pinzon, T.; Rieradevall, J.; Gasol, C.M.; Gabarrell, X. Modelling for economic cost and environmental analysis of rainwater harvesting systems. J. Clean. Prod. 2015, 87, 613-626. [CrossRef]

37. Haque, M.M.; Rahman, A.; Samali, B. Evaluation of climate change impacts on rainwater harvesting. J. Clean. Prod. 2016, 137, 60-69. [CrossRef]

38. Kumar, M.D. Roof water harvesting for domestic water security: Who gains and who loses? Water Int. 2004, 29, 43-53. [CrossRef]

39. Roebuck, R.M.; Oltean-Dumbrava, C.; Tait, S. Whole life cost performance of domestic rainwater harvesting systems in the United Kingdom. Water Environ. J. 2011, 25, 355-365. [CrossRef]

40. Rahman, A.; Dbais, J.; Imteaz, M. Sustainability of rainwater harvesting systems in multistory residential buildings. Am. J. Eng. Appl. Sci. 2010, 3, 889-898. [CrossRef]

41. Imteaz, M.A.; Shanableh, A.; Rahman, A.; Ahsan, A. Optimisation of rainwater tank design from large roofs: A case study in Melbourne, Australia. Resour. Conserv. Recycl. 2011, 55, 1022-1029. [CrossRef]

42. Domenech, L.; Saurí, D. A comparative appraisal of the use of rainwater harvesting in single and multi-family buildings of the Metropolitan Area of Barcelona (Spain): Social experience, drinking water savings and economic costs. J. Clean. Prod. 2011, 19, 598-608. [CrossRef]

43. Ghisi, E.; Schondermark, P.N. Investment feasibility analysis of rainwater use in residences. Water Resour. Manag. 2013, 27, 2555-2576. [CrossRef]

44. Ojwang, R.O.; Dietrich, J.; Anebagilu, P.K.; Beyer, M.; Rottensteiner, F. Rooftop rainwater harvesting for Mombasa: Scenario development with image classification and water resources simulation. Water 2017, 9, 359. [CrossRef] 
45. Adham, A.; Riksen, M.; Ouessar, M.; Ritsema, C. A methodology to assess and evaluate rainwater harvesting techniques in (semi-) arid regions. Water 2016, 8, 198. [CrossRef]

46. Sámano-Romero, G.; Mautner, M.; Chávez-Mejía, A.; Jiménez-Cisneros, B. Assessing marginalized communities in Mexico for implementation of rainwater catchment systems. Water 2016, 8, 140. [CrossRef]

47. Melville-Shreeve, P.; Ward, S.; Butler, D. Rainwater harvesting typologies for UK houses: A multi criteria analysis of system configurations. Water 2016, 8, 29. [CrossRef]

48. Liuzzo, L.; Notaro, V.; Freni, G. A reliability analysis of a rainfall harvesting system in Southern Italy. Water 2016, 8, 18. [CrossRef]

49. Liang, X.; Dijk, M.P.V. Identification of decisive factors determining the continued use of rainwater harvesting systems for agriculture irrigation in Beijing. Water 2016, 8, 7. [CrossRef]

50. Chiu, Y.R.; Tsai, Y.L.; Chiang, Y.C. Designing rainwater harvesting systems cost-effectively in a urban water-energy saving scheme by using a GIS-simulation based design system. Water 2015, 7, 6285-6300. [CrossRef]

51. Huang, C.L.; Hsu, N.S.; Wei, C.C.; Luo, W.J. Optimal spatial design of capacity and quantity of rainwater harvesting systems for urban flood mitigation. Water 2015, 7, 5173-5202. [CrossRef]

52. Lizárraga-Mendiola, L.; Vázquez-Rodríguez, G.; Blanco-Piñón, A.; Rangel-Martínez, Y.; González-Sandoval, M. Estimating the rainwater potential per household in an urban area: Case study in Central Mexico. Water 2015, 7, 4622-4637. [CrossRef]

(C) 2017 by the author. Licensee MDPI, Basel, Switzerland. This article is an open access article distributed under the terms and conditions of the Creative Commons Attribution (CC BY) license (http://creativecommons.org/licenses/by/4.0/). 